\title{
Physicochemical Properties of Processed Aerial Yam (Dioscorea bulbifera) and Sensory Properties of Paste (Amala) Prepared with Cassava Flour
}

\author{
R. M. O. Kayode ${ }^{*}$, O. J. Buhari', L. O. Otutu ${ }^{3}$, T. B. Ajibola ${ }^{2}$, S. A. Oyeyinka ${ }^{1}$, \\ D. O. Opaleke ${ }^{1}$ and S. A. Akeem ${ }^{1}$ \\ Received: $15^{\text {th }}$ July 2016 / Accepted: $11^{\text {th }}$ September 2016
}

\begin{abstract}
Aerial yam is a member of the Dioscoreaceae family which consist several varieties found in South Asia and Africa. The tubers are under-utilized and not commercially grown; but are cultivated and consumed among rural dwellers in parts of Western Nigeria. The tubers were washed, sorted, peeled, sliced and blanched in hot water at $80^{\circ} \mathrm{C}$ for $10 \mathrm{~min}$. The blanched yam slices were divided into four portions. Two portions were fermented for $48 \mathrm{hr}$ and sun (BFSUD) and solar (BFSOD) dried. The other two blanched portions were also sun (BSUD) and solar (BSOD) dried respectively. The dried slices were milled, sieved and used for proximate, functional and phytochemical analysis. Proximate composition of aerial yam flour was: moisture content (7.66-10.60\%), total ash (0.05-1.76\%), crude protein (4.42-5.07\%), crude fibre (0.56-0.69\%), crude fat (3.42-3.82\%), and carbohydrate (79.28-82.37\%). The phytochemical constituent included alkaloid, steroids, saponin and flavonoid. The bulk density, water absorption capacity and dispersibility were within the range of $0.52-0.54 \mathrm{~g} / \mathrm{ml}, 56.50-66.00 \mathrm{~g} / \mathrm{g}$ and $4.47-5.75 \%$ respectively. The sample, BFSUD had the highest crude protein, dispersibility and water absorption capacity was selected and mixed with cassava flour for amala on which sensory evaluation was conducted. Five aerial yam flour (AY) treatments were formulated and coded as follow: $A Y_{100,} A Y_{80} C S_{20,} A Y_{60} C S_{40,} A Y_{40} C S_{60}$ and $A Y_{20} C S_{80}$. Cassava flour $\left(C S_{100}\right)$ was used as control treatment. The overall acceptability of flour paste (amala) ranged from 5.45 (Sample $A Y_{80} C S_{20}$ ) to 7.25 (sample $A Y_{100}$ ). The study revealed treatment $A Y_{60} C S_{40}$ and $A Y_{80} C S_{20}$ possessed the overall acceptability, mean score above 7.0 (like slightly). Therefore 60-80\% incorporation of aerial yam flour with cassava is recommended based on desirable sensory characteristics. Aerial yam flour can be used for food preparation and commercial purpose which may in turn increase the utilization.
\end{abstract}

Keywords: Aerial yam, Amala, Cassava, Composite flour

\section{INTRODUCTION}

Roots and tubers can basically provide energy from carbohydrate in human diet as minerals and some essential vitamins in human diets (Hahn, 1995). High moisture content of these crops result in short storage life at ambient condition. Root crops have been regarded as food for the poor and less popular in the international trade due to lack of appreciation (FAO, 1990).

Yams are the edible tubers of various species of the genus Dioscorea and considered as staple foods of many tropical countries including Cộte d'Ivoire, Ghana, Togo, Burkina Faso and Nigeria (Kouakou et al., 2010; Amanze et al., 2011). Yam is cultivated mainly in three areas of the world; namely West Africa, parts East-Central and Southern Africa (FAO, 1999) and produce about $95 \%$ of the world yam production, followed by South-East Asia including China, Japan and Oceania. The third area includes the Caribbean, Mexico, and parts of Central America (FAO, 1999). Yams serve

\footnotetext{
1. Division of Food Processing, Preservation, Microbial Biotechnology, Toxicology and Safety, Department of Home Economics and Food Science, University of Ilorin, P.M.B 1515, Nigeria.kayodermosnr@gmail.com

2. Department of Physics, University of Ilorin, P.M.B 1515, Ilorin, Nigeria.

3. Department of Food Science and Technology, Joseph Ayo Babalola University, Keji-Arakeji, Nigeria.
} 
as a major contributor to food security in West Africa (Zannou, 2006), but out of the over 600 known yam species, only seven are mostly consumed (Jayakody et al., 2007). These include Dioscorea rotundata Poir (White yam), Dioscorea cayenensis (Yellow yam), Dioscorea alata (Water yam), Dioscorea bulbifera (Aerial yam), Dioscorea esculenta, Dioscorea praehensalis (Bush yam) and Dioscorea dumetorum (Bitter yam). D. rotundata is the most important species grown and consumed in Ghana, in terms of area planted and quantity produced (Otoo and Asiedu, 2008). In Nigeria, yam is one of the major crops in the farming systems and commercially produces different varieties of $D$. rotundata. D. cayenensis, $D$. bulbifera, $D$. dumentorum and $D$. esculenta are cultivated in lesser quantity for domestic use (Tetteh and Saakwaa, 1994).

The edible species of $D$. bulbifera are grown extensively in West Africa, Carribean Islands, South-East Asia, South Pacific and West Indies. The wild forms occur in both Africa and Asia. D. bulbifera is used as food and it provides substantial amount of calories and minerals such as iron, calcium and phosphorous (Tindall, 1983; Abara et al., 2000). Dioscorea bulbifera tuber is a rich source of starch that forms an important dietary supplement (Deb, 2002). Apart from starch, the root tubers of Dioscorea species contain protein, fat, fiber and some minerals such as Potassium, Sodium, Phosphorus, Calcium, Magnesium, Copper, Iron, Manganese, Zinc and Sulphur (Deb, 2002). "Diosgenin" is a pharmacologically active component of Dioscorea obtained from root and rhizomes which is one of the most costly and important steroidal drug used worldwide (Sharma, 2004). Dietary PEs (plant estrogens) of Dioscorea can provide a wide range of health benefits including protection against development of cancer, osteoporosis, cardiovascular disease, nephritis, asthma, diabetes, and used in the preparation of contraceptives and in the treatment of various genetic disorders (Ayoola et. al., 2008). Aerial yam also known as air potato, Adun, Odun,
Kanduin in some regions of Nigeria though predominantly in the Western and Eastern regions is grown for its bulbils and eaten during the famine season. Even though it possesses a distinctive flavour and comparable in nutritional content to the most preferred yam species, it does not possess the same appeal compared to $D$. alata $L$. and D. rotundata Poir. The yam is unpopular; less studied, and received minimal interest and attention by food processor in Nigeria. The high rate of post-harvest losses of the crop and inadequate method of preservation probably resulted in it's under exploitation as foodstuff and industrial uses.

Cassava (Manihot esculenta crantz) is one of the few most important root crops known and used in many countries of Africa, Latin America and some Asian countries. Though it has origin at South America, cassava has become an indigenous crop in the tropics having been widely grown and used. Cassava is a staple food for over 500 million people in the developing world (Cock, 1985). It has played vital roles in the diets of many African countries as a major source of low cost carbohydrate (O'Hair, 1990). The emphasis on protein deficiency of cassava is due to ignorance of food habits in regions where cassava is the people's main food (Ihekoronye and Ngoddy, 1985). This research is designed to determine the physicochemical properties of differently processed and dried aerial "yam" $(D$. bulbifera) and to assess the sensory properties of Amala (paste) produced from the composite flour mixture with cassava flour.

\section{MATERIALS AND METHODS}

\section{Source of sample}

D. bulbifera was purchased from local market in Aduratedo-Ape, Kabba, Bunu LGA, Kogi State, Nigeria, while Cassava flour (Lafun) was sourced from Oja-Oba market in Ilorin, Kwara State, Nigeria. 
Processing of Dioscorea bulbifera tubers for flour production

The tubers of D. bulbifera were washed with clean water to remove adhering soil and other undesirable materials. The yam samples were sorted and hand-peeled using kitchen knives and then sliced into sizes of 2 to $3 \mathrm{~cm}$ in thickness. The sliced yam was soaked in water at $50^{\circ} \mathrm{C}$ while, peeling to avoid enzymatic browning and also to remove the bitter compound from the sliced samples. The slices were blanched with hot water at $80^{\circ} \mathrm{C}$ for $10 \mathrm{~min}$. The blanched yam slices were then divided into four portions. Two portions of the treatment samples were returned to the steep water and allowed to undergo natural fermentation for 48hours before it was drained.

A portion of the blanched sample and the blanched-fermented sample were sun-dried to constant weight within five days, while the other portion were dried for 5 days in a glass solar dryer fabricated in the Department of Physics, University of Ilorin, Nigeria. Temperature

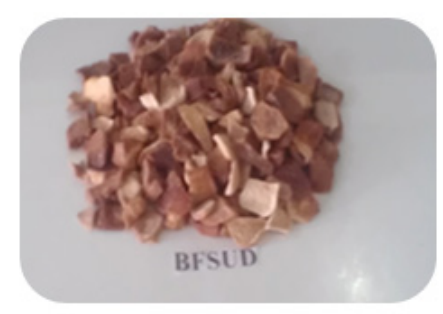

BFSUD

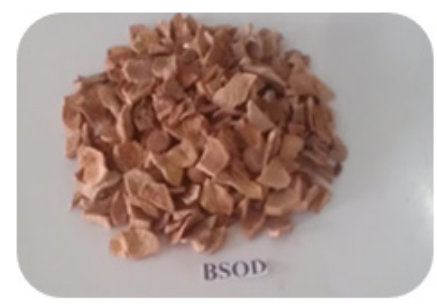

BSOD $\left(55^{\circ} \mathrm{C}\right)$ and relative humidity $(16.4 \%)$ were controlled in the solar dryer.

The dried yam slices were milled using locally fabricated hammer mill and screened $(1 \mathrm{~mm}$ sieve) to aerial yam flour and then stored in an air tight container prior to analysis. The differently processed and dried samples of $D$. bulbifera are presented in Figure 01.

\section{Proximate analysis of processed aerial yam flour}

The proximate composition of the aerial yam flour samples were analyzed using the standard methods of AOAC (2005). The samples were analyzed for moisture, total ash, crude fibre, crude fat, crude protein and carbohydrate (by difference).

\section{Phytochemical screening of aerial yam flour}

Qualitative phytochemical screening was carried out on the aerial yam flour samples using the standard procedures of Safowora (1993) and Evans (1996).

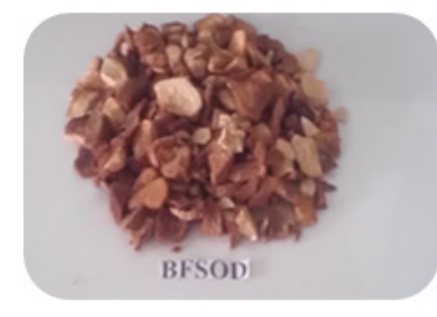

BFSOD

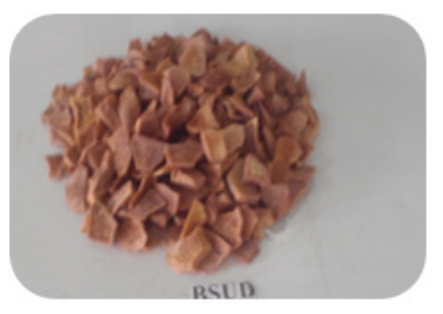

BSUD

BFSUD: Blanched fermented sun-dried BFSOD: Blanched fermented solar-dried BSUD: Blanched sun-dried

BSOD: Blanched solar-dried

Figure 01: Processed and dried samples of aerial yam (D. bulbifera) 
Water Absorption Capacity of the Aerial yam flour

Water absorption capacity of the flour samples were determined by difference (Abbey and Ibeh, 2000). Two grams of the flour sample was weighed into centrifuge tube, $20 \mathrm{ml}$ of distilled water was added, the tube containing the sample was carefully shaken by vortex and allowed to stand at room temperature $\left(25^{\circ} \mathrm{C}\right)$ for $30 \mathrm{~min}$., it was centrifuge for $30 \mathrm{~min}$. at 200 rpm, excess water was decanted by inverting the tube, the weight of the water was determined by difference as follow:

Water absorption capacity $(\%)=\left(\mathrm{W}_{1}-\mathrm{W}_{2}\right) / \mathrm{W}_{\mathrm{S}}$ $\mathrm{x} 100$

Where:

$\mathrm{W}_{1}=$ Weight of residue in tube after centrifuge

$\mathrm{W}_{2}=$ Weight of empty tube before centrifuge

$\mathrm{W}_{\mathrm{S}}=$ Weight of sample used

\section{Determination of Bulk Density of the flour}

The bulk density of the aerial yam flour samples was determined according to the method of Giami, et al. (1992). Five grams of the sample was weighed into $50 \mathrm{ml}$ graduated measuring cylinder. The sample was gently packed by tapping the cylinder on the bench top 10 times from height of $5 \mathrm{~cm}$. The volume of the sample was recorded and bulk density calculated.

Bulk density $(\mathrm{g} / \mathrm{ml})=$ (Weight of sample used/ Volume of sample after tapping)

\section{Assessment of dispersibility of aerial yam flour}

The method described by Kulkarni et al. (1991) was used to measure the dispersibility. Ten grams sample of flour was weighed into $100 \mathrm{ml}$ capacity measuring cylinder, and water added up to $100 \mathrm{ml}$ mark of the measuring cylinder. The set up was stirred vigorously and allowed to settle for $3 \mathrm{hr}$. The volume of settled particles was recorded and subtracted from 100. The difference was then reported as percentage dispersibility (Kulkarni et al., 1991).

Dispersibility $(\%)=100-$ Volume of settled particle

\section{Sensory evaluation of Amala produced from composite flours of aerial yam and cassava}

The samples of $D$. bulbifera and cassava (Lafun) flours are shown in Figure 02. After analysis of the flour obtained from the four differently processed and dried aerial yam samples namely: BFSUD, BFSOD, BSOD and BSUD, The sample BFSUD, which had the highest crude protein and functional attributes was selected for the formulation of the aerial yam-cassava flour mixtures. The aerial yam and cassava flours were mixed at different ration as follow: 100:0 $\left(\mathrm{AY}_{100}\right), 80: 20\left(\mathrm{AY}_{80} \mathrm{CS}_{20}\right), 60: 40\left(\mathrm{AY}_{60} \mathrm{CS}_{40}\right)$, 40:60 $\left(\mathrm{AY}_{40} \mathrm{CS}_{60}\right), 20: 80\left(\mathrm{AY}_{20} \mathrm{CS}_{80}\right)$ and 0:100 $\left(\mathrm{CS}_{100}\right.$; used as control). The six flour treatment samples were used to prepare flour paste called "Amala" in the Western part of Nigeria. Two hundred grams of each sample was weighed and continuously stirred with $150 \mathrm{ml}$ of boiling water until properly cooked to produce a smooth paste (Amala). Sensory attributes (taste, colour, flavour, texture and overall acceptability) were tested using Hedonic scale (9 points) with 20 consumers on reconstituted hot paste of flour (Amala) were asked to evaluate the prepared hot aerial yam flour pastes (Amala) Ihekoronye and Ngoddy, (1985).

\section{Statistical analysis}

Data were subjected to analysis of variance using SPSS version 16.0, while means were separated using Duncan's Multiple Range Test (Duncan, 1955). 

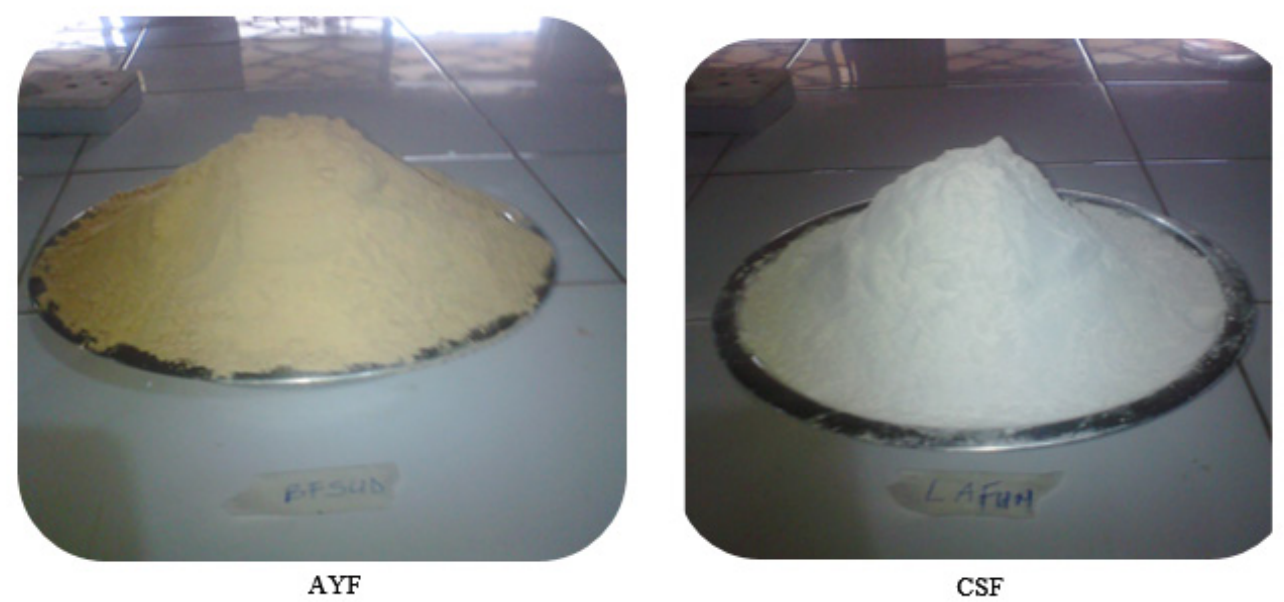

Figure 02: Representative sample of aerial yam (AYF) and cassava (CSF) flours

\section{RESULTS AND DISCUSSION}

\section{Effect of processing methods on proximate composition of aerial yam (D. bulbifera) flour}

The proximate composition of aerial yam flour is given in Table 1 . The moisture content on dry basis ranged from $7.66 \%$ (BSOD) to $10.60 \%$ (BFSOD). These values were close to the value $(8.33 \%)$ reported by Abara et al., (2003) in the dry tissue of $D$. bulbifera. There was a significant difference $(p<0.05)$ in the moisture content of the samples investigated (Table 01).

Total ash content of the sample ranged from $0.05 \%$ (BFSUD) to $1.76 \%$ (BFSOD). The result showed that there was significant difference $(p<0.05)$ between the studied samples. The total ash of roots and tubers were reported as $0.6 \%$ to as high as $1.7 \%$ on wet basis (FAO, 1968; 1972; Watson, 1971; Eka, 1978; Abara et al., 2003) and between $2.24 \%$ and $5.16 \%$ on dry basis (Oyenuga, 1968; Abara et al., 2003) on yam tubers. Mineral content of foods varied but generally substantial amounts of mineral and trace elements is available. The mineral element depends on the chemical composition of soil, cultural practices, time of planting and the amount of water available to the tuber plant (Osagie, 1992). FAO (1968; 1972) reported the ash content of a sample of wet tissue of $D$. bulbifera as $1.0 \%$. Abara et al. (2003) reported a value of $1.21 \%$ and Coursey (1983) reported a range of 1.1 to $1.5 \%$ of ash content.

Table 01: Proximate Composition of the aerial yam (D. bulbifera) flour

\begin{tabular}{lcccccc}
\hline \multirow{2}{*}{$\begin{array}{c}\text { Sample } \\
\text { Code }\end{array}$} & \begin{tabular}{c} 
Moisture \\
\cline { 2 - 6 }
\end{tabular} & $\begin{array}{c}\text { Total } \\
\text { Content }(\%)\end{array}$ & $\begin{array}{c}\text { Crude Protein } \\
(\%)\end{array}$ & $\begin{array}{c}\text { Crude Fat } \\
(\%)\end{array}$ & $\begin{array}{c}\text { Crude Fibre } \\
(\%)\end{array}$ & $\begin{array}{c}{ }^{*} \text { Carbohydrate } \\
(\%)\end{array}$ \\
\hline BFSUD & $10.21 \pm 0.21^{\mathrm{b}}$ & $0.15 \pm 0.00^{\mathrm{c}}$ & $5.07 \pm 0.00^{\mathrm{a}}$ & $3.63 \pm 0.02^{\mathrm{b}}$ & $0.67 \pm 0.00^{\mathrm{a}}$ & $70.24 \pm 0.76^{\mathrm{b}}$ \\
BFSOD & $10.60 \pm 0.14^{\mathrm{a}}$ & $1.76 \pm 0.00^{\mathrm{a}}$ & $4.42 \pm 0.86^{\mathrm{a}}$ & $3.36 \pm 0.01^{\mathrm{c}}$ & $0.56 \pm 0.00^{\mathrm{c}}$ & $73.28 \pm 1.00^{\mathrm{a}}$ \\
BSOD & $7.66 \pm 0.19^{\mathrm{d}}$ & $0.73 \pm 0.02^{\mathrm{b}}$ & $4.70 \pm 1.39^{\mathrm{a}}$ & $3.82 \pm 0.03^{\mathrm{a}}$ & $0.69 \pm 0.00^{\mathrm{a}}$ & $75.39 \pm 1.22^{\mathrm{a}}$ \\
BSUD & $9.43 \pm 0.02^{\mathrm{c}}$ & $0.05 \pm 0.00^{\mathrm{d}}$ & $4.48 \pm 0.46^{\mathrm{a}}$ & $3.42 \pm 0.04^{\mathrm{c}}$ & $0.61 \pm 0.02^{\mathrm{b}}$ & $75.89 \pm 0.56^{\mathrm{a}}$ \\
\hline
\end{tabular}

Means within column with different superscripts indicates significant difference $(\mathrm{P} \leq 0.05)$;

${ }^{*}$ Calculated by difference.

BFSUD $=$ Blanched fermented sun-dried

BFSOD $=$ Blanched fermented solar-dried

BSUD $=$ Blanched sun-dried

BSOD $=$ Blanched solar-dried 
There was no significant difference $(p>0.05)$ in protein content of the treated samples. The values were ranged from $4.42 \%$ (BFSOD) to $5.07 \%$ (BFSUD). Bell and Favier (1981) reported a fairly high range of crude protein from $6 \%-9 \%$ on dry basis. Martin (1979), Barquar and Oke (1976) also reported higher protein levels of between 7.9 and $9.6 \%$ and $6.7-11.1 \%$ respectively for $D$. bulbifera on dry matter basis. Abara et al. (2003) also reported a figure of $5.75 \%$ in the dry tissue of $D$. bulbifera. Martin (1979) had reported that crude protein content of yam varied considerably among species and between cultivars and attributed the variations in the proximate principles to factors such as climatic condition, stage of maturity at harvest and length of storage time. These factors may be responsible for the amount of crude protein observed in the processed $D$. bulbifera tubers that was used for flour production in this study.

The crude fat in aerial yam flour ranged from 3.36-3.82\%. Sample BSOD was significantly higher $(\mathrm{p}>0.05)$ when compared with other samples (Table 1). The crude fat of the treatment samples were close to values ranging from 2.24 to $5.16 \%$ as earlier reported by Oyenuga (1968) and Abara et al. (2003).

The crude fibre and total carbohydrate content of the samples ranged from $0.56 \%$ (BFSOD) to $0.69 \%$ (BSOD) and $70.24 \%$ (BFSUD) to $75.89 \%$ (BSUD) respectively. Crude fibre consists principally of cellulose and lignin together with small amounts of hemicellulose (Southgate, 1973). A similar value of crude fibre $(0.72 \%)$ in D. bulbifera was reported by Coursey (1983) while higher values of $1.20 \%$ and $1.39 \%$ crude fibre were reported by FAO $(1968 ; 1972)$ and Abara et al. (2003) respectively. The variation in recorded values in proximate composition of the treated D. bulbifera samples might be due to the differences in processing and drying methods in flour production. Baah (2009) and Shanthakumari et al. (2008) reported similar high carbohydrate content for D. bulbifera. Abara et al. (2003) reported a value of $80.98 \%$ in the dry tissue of $D$. bulbifera.

Carbohydrate content constitutes the major dry matter component of all the dried D. bulbifera samples as same as in other yam varieties (Oyenuga, 1968; Ihekeronye and Ngoddy, 1985; Osagie, 1992).

\section{Effect of processing methods on functional properties of aerial yam (D. bulbifera) flour}

The functional properties of the aerial yam flour indicated water absorption capacity (WAC) ranging from $4.47 \mathrm{~g} / \mathrm{g}$ (Sample BSOD) to $5.75 \mathrm{~g} / \mathrm{g}$ (Sample BFSUD) (Table 02). The WAC of samples BFSUD and BFSOD were significantly higher $(p>0.05)$ than other treatments. Hydrolytic effect of fermentation process may increase the WAC in aerial yam. Water absorption capacity of flour gives an idea of swelling capacity of starch granules during reconstitution (Adebowale et al., 2005; Oladipo and Nwokocha, 2011).

Bulk density of flour is ranged from $0.52 \mathrm{~g} /$ $\mathrm{ml}$ (BFSUD) to $0.54 \mathrm{~g} / \mathrm{ml}$ (BSOD). There was no significant difference $(p<0.05)$ among treatments. Bulk density is generally affected by particle size, density of flour or flour blends and signified possibilities in packaging requirement, raw material handling and application in wet processing (Adebowale et al., 2008a; Ajanaku et al., 2012). The result of dispersibility which ranged from $56 \%$ (BFSUD) to $66 \%$ (BFSOD) of values indicated that flour could be easily reconstituted in water during preparation. Dispersibility is an index of the ease of reconstitution of flour into a fine consistency paste during stirring (Adebowale et al., 2008a). 
Table 02: Functional properties of the aerial yam ( $D$. bulbifera) flour

\begin{tabular}{cccc}
\hline \multirow{3}{*}{ Sample Code } & \multicolumn{3}{c}{ Functional Property } \\
\cline { 2 - 4 } & Bulk Density $(\mathrm{g} / \mathrm{ml})$ & Dispersability $(\%)$ & WAC $(\%)$ \\
\hline BFSUD & $0.52 \pm 0.00^{\mathrm{a}}$ & $66.50 \pm 0.50^{\mathrm{a}}$ & $5.75 \pm 0.02^{\mathrm{a}}$ \\
BFSOD & $0.53 \pm 0.00^{\mathrm{a}}$ & $66.00 \pm 0.00^{\mathrm{a}}$ & $5.73 \pm 0.02^{\mathrm{a}}$ \\
BSOD & $0.54 \pm 0.00^{\mathrm{a}}$ & $60.50 \pm 0.70^{\mathrm{b}}$ & $4.47 \pm 0.02^{\mathrm{c}}$ \\
BSUD & $0.53 \pm 0.00^{\mathrm{a}}$ & $62.50 \pm 0.41^{\mathrm{b}}$ & $4.82 \pm 0.01^{\mathrm{b}}$ \\
\hline
\end{tabular}

Means within column with different superscripts indicates significant difference $(\mathrm{P} \leq 0.05)$;

WAC $=$ Water Absorption Capacity.

BFSUD $=$ Blanched fermented sun-dried

$\mathrm{BFSOD}=$ Blanched fermented solar-dried

BSUD $=$ Blanched sun-dried

BSOD $=$ Blanched solar-dried

\section{Phytochemical composition of aerial yam (Dioscorea bulbifera) flour}

The Phytochemical constituent of aerial flour processed in different methods is given in Table 03. The result shows presence of flavanoids, alkaloids, saponin, and steroids. Diosgenin, a steroid sapogenin extracted from yam, is used as precursor for the synthesis of hormones and corticosteroids which improve fertility in males (Djerassi1992). Saponins possesses both beneficial effects (cholesterollowering) and deleterious properties (cytotoxic permeabilization of the intestine) and also exhibit structure dependent biological activities (Prohp and Onoagbe, 2012). The biological functions of flavonoids apart from its antioxidant properties include; protection against allergies, inflammation, free radicals, platelet aggregation, microbes, ulcers, hepatoxins, viruses and tumors (Trease and Evans, 2002). Alkaloid has been used for over two centuries as stimulant and is active against bacteria (Madziga et al., 2010). Tannin was not detected in the processed aerial yam. This perhaps could probably justify the use of it flour as the anti-nutritional factor such as tannin which could be inhibitory to bioavailability of minerals and vitamins and affect digestibility and palatability of protein was not detected.
Sensory Evaluation of paste (Amala) produced from the composite flours of aerial yam (D. bulbifera) and cassava

The mean scores of sensory evaluation of "Amala" produced from composite flours of aerial yam and cassava is given in Table 04 . Colour of the aerial yam-cassava composite flour is ranged from $6.75\left(\mathrm{AY}_{20} \mathrm{CS}_{80}\right)$ to 7.45 $\left(\mathrm{AY}_{40} \mathrm{CS}_{60}\right)$. There was no significant difference $(p>0.05)$ in ranking colour of amala among the six treatments. However, there was a significantly higher value $(p>0.05)$ than both sample $\mathrm{AY}_{100}$ (6.15) and the control (5.75).

The taste and texture of sample $\mathrm{AY}_{60} \mathrm{CS}_{40}$ were the most acceptable by the panelists, while those of sample $\mathrm{A}_{100} \mathrm{C}_{0}$ were the least acceptable. Treatment $\mathrm{AY}_{80} \mathrm{CS}_{20}$ was scored the highest mean values for aroma (7.30) and overall acceptability (7.27). The overall acceptability for sample $\mathrm{AY}_{60} \mathrm{CS}_{40}$ and $\mathrm{AY}_{80} \mathrm{CS}_{20}$ were 7.27 and 7.23 respectively. Therefore $60-$ $80 \%$ substitution of aerial yam into cassava flour is more acceptable by panelists and this range $(60-80 \%)$ is recommended for use in flour formulations for desirable sensory characteristics. 
Table 03: Phytochemical composition of the aerial yam (D. bulbifera) flour

\begin{tabular}{lccccc}
\hline \multirow{2}{*}{ Treatment Samples } & \multicolumn{5}{c}{ Phytochemical composition } \\
\cline { 2 - 5 } & Alkaloid & Saponin & Steroid & Flavonoid & Tannin \\
\hline Blanched fermented sun-dried & ++ & + & + & ++ & - \\
Blanched fermented solar-dried & + & + & + & ++ & - \\
Blanched solar-dried & + & + & + & ++ & - \\
Blanched sun-dried & + & + & + & ++ & - \\
\hline
\end{tabular}

Key: $+=$ Present in low concentration, $++=$ Present in high concentration, - = Absent.

Table 04: Sensory evaluation of "Amala" prepared from a composite flour of aerial yam (D. bulbifera) and cassava

\begin{tabular}{lccccc}
\hline \multirow{2}{*}{ Sample Code } & \multicolumn{5}{c}{ Sensory characteristics } \\
\cline { 2 - 5 } & Colour & Taste & Aroma & Texture & Overall Acceptability \\
\hline $\mathrm{AY}_{100}$ & $6.15^{\mathrm{b}}$ & $4.70^{\mathrm{b}}$ & $5.40^{\mathrm{b}}$ & $5.65^{\mathrm{b}}$ & $5.45^{\mathrm{b}}$ \\
$\mathrm{AY}_{80} \mathrm{CS}_{20}$ & $7.40^{\mathrm{a}}$ & $6.50^{\mathrm{a}}$ & $7.30^{\mathrm{a}}$ & $6.85^{\mathrm{a}}$ & $7.27^{\mathrm{a}}$ \\
$\mathrm{AY}_{60} \mathrm{CS}_{40}$ & $7.25^{\mathrm{a}}$ & $6.95^{\mathrm{a}}$ & $7.05^{\mathrm{a}}$ & $7.15^{\mathrm{a}}$ & $7.23^{\mathrm{a}}$ \\
$\mathrm{AY}_{40} \mathrm{CS}_{60}$ & $7.45^{\mathrm{a}}$ & $6.15^{\mathrm{a}}$ & $7.05^{\mathrm{a}}$ & $6.85^{\mathrm{ab}}$ & $6.75^{\mathrm{ab}}$ \\
$\mathrm{AY}_{20} \mathrm{CS}_{80}$ & $6.75^{\mathrm{a}}$ & $5.80^{\mathrm{ab}}$ & $7.04^{\mathrm{a}}$ & $6.25^{\mathrm{ab}}$ & $6.70^{\mathrm{ab}}$ \\
$\mathrm{CS}_{100}($ Control $)$ & $5.75^{\mathrm{c}}$ & $6.15^{\mathrm{ab}}$ & $6.85^{\mathrm{a}}$ & $6.35^{\mathrm{ab}}$ & $6.30^{\mathrm{ab}}$ \\
\hline
\end{tabular}

"Means within row with different superscripts indicates significant difference $(\mathrm{P} \leq 0.05)$

$\mathrm{AY}_{100}=100 \%$ Aerial Yam and $0 \%$ Cassava

$\mathrm{AY}_{80} \mathrm{CS}_{20}=80 \%$ Aerial Yam and 20\% Cassava

$\mathrm{AY}_{60} \mathrm{CS}_{40}=60 \%$ Aerial Yam and $40 \%$ Cassava

$\mathrm{AY}_{40} \mathrm{CS}_{60}=40 \%$ Aerial Yam and 60\% Cassava

$\mathrm{AY}_{20} \mathrm{CS}_{80}=20 \%$ Aerial Yam and $80 \%$ Cassava

$\mathrm{CS}_{100}($ Control $)=0 \%$ Aerial Yam and $100 \%$ Cassava

\section{CONCLUSION}

The fermentation of aerial yam accompanied with sun and solar drying processes had positive influence on swelling capacity and ease of reconstitution of the composite flour into a fine consistency paste. Substitution of cassava flour with aerial yam flour (60 to $80 \%$ ) had a more desirable and acceptable products. The phytochemical composition of the aerial yam flour proved the evidence of health beneficial and nutrient bioavailability. Application of these findings in domestic and industrial purpose will provide a nutrient dense product; thus enhance the utilization of aerial yam.

\section{REFERENCES}

Abara, A.E., Udosen, E.O., and Eka, O.U. (2003). Moisture content and polyphenol oxidase activity of growing Dioscorea bulbifera as indicators of tuber maturation. Global. Journal of Pure Applied Science, 9: 113-115. DOI: http://dx.doi.org/10.4314/gjpas.v9i1.16045

Adebowale, A.A., Sanni, L.O., and Awonarin, S.O. (2005). Effect of texture modifies on the physicochemical and sensory properties of dried fufu. Food Science and Technology Intstitute, 11: 373-385. DOI: http://dx.doi.org/10.1177/1082013205058531 
Adebowale, A.R.A, Sanni, S.A. and Oladapo, F.O. (2008). Chemical, functional and sensory properties of instant yam-breadfruit flour. Nigerian Food Journal, 26: 2-12. DOI: http:// dx.doi.org/10.4314/nifoj.v26i1.47417

Ajanaku, K.O., Ajanaku, C.O. Edobor-Osoh, A. and Nwinyi, O.C. (2012). Nutritive value of Sorghum Ogi fortified with groundnut seed (Arachis hypogaea L.). American Journal of Food Technology, 7: 82-88. DOI: http://dx.doi.org/10.3923/ajft.2012.82.88

AOAC (2005). Official methods of analysis of AOAC International; Horwitz W, editor. Gaithersburg, MD, Washington, DC, USA: AOAC International. PMID: 15759755. DOI: http://dx.doi.org/10.5740/jaoacint.14-194

Ayoola, G.A., Coker, H.A.B., Adesegun, S.A., Adepoju-Bello, A.A., Obaweya, K., Ezennia, E.C. (2008). Phytochemical Screening and anti-oxidant activities of some Selected Medicinal Plant used for malaria therapy in South-western Nigeria. Tropical Journal of Pharmaceutical Research, 7(3):1019-1014. DOI: http://dx.doi.org/10.4314/tjpr.v7i3.14686

Baah, F.D. (2009). Charaterization of water yam (Dioscorea alata) for existing and potential food products. Faculty of Biosciences, College of Sciences, Kwame Nkrumah University of Science and Technology, Kumasi Ghana. Ph.D. Thesis. DOI: http://dx.doi.org/10.21315/ jedc2016.21.2.7

Bell, A., and Favier, J.C. (1981). Effect of traditional food processing methods on nutritional value of yam in Cameroon. Tropical root crops: Production 1 Triennial root crops symposium, Ibadan. 163: 214-224. DOI: http://dx.doi.org/10.1002/9780470168721.ch5

Coursey, D.G., (1983). Yams. In: Handbook of tropical foods (Chan, H.V., edition) Marcel Dekker, Incorporation. New York and Basel, Pp: 555-601. DOI: http://dx.doi.org/10.1002/ food. 19850290917

Deb, A.C. (2002). Fundamental of Biochemistry. Eds 8, New Central Book Agency, Kolkata. DOI: http://dx.doi.org/10.1023/b:biry.0000040228.89036.46

Djerassi, C. (1992). Steroid research at Syntex: "the pill" and cortisone". Steroids 57 (12): 63-41. DOI: http://dx.doi.org/10.1016/0039-128x(92)90016-3

Duncan, D.B. (1955). Multiple Range and Multiple F-test. Biometrics 11: 1-5. DOI: http://dx.doi. org/10.2307/3001478

Edeoga, H.A., Okwu, D.E., and Mbaebie, B.O. (2005). Phytochemical constituent of some Nigerian Medicinal plants. African Journal of Biotechnology, 4(7):685-688. DOI: http:// dx.doi.org/10.5897/ajb2005.000-3127

Eka, O.U. (1978). Chemical evaluation of the nutritive value of soya paps and porridges, the Nigerian weaning foods. Food Chemistry, 3: 199-206. DOI: http://dx.doi.org/10.1016/03088146(78)90019-5

FAO (1968). Food composition table for use in Africa. Food and Agriculture Organization, Rome, Italy. DOI: http://dx.doi.org/10.2172/1329289 
FAO (1972). Food Composition table for use in East Asia. Food and Agriculture Organization, Rome, Italy. DOI: http://dx.doi.org/10.2172/1329289

FAO (1990). Food and Agriculture Organization. Action Programme for the prevention of food losses, improving post-harvest handing, storage and processing of root and tube crops, Rome, Italy. DOI: http://dx.doi.org/10.2172/1329289

FAO (1999). Food and Agriculture Organization of the United Nations. Production yearbook volume 53. FAO statistics, 1999. FAO, Rome, Italy. DOI: http://dx.doi.org/10.18356/73becce3-en

Giami, S.Y., Bekebian, O.A., and Emelike, N.J.T. (1992). Proximate and functional properties of winged bean (Phosphoearpus tetragonolobus), Nigerian Journal of Nutritional Science, Vol. B (182). DOI: http://dx.doi.org/10.1111/j.1365-2621.1987.tb13982.x

Hahn, S.K. (1995). Yams: Dioscorea species (Dioscoreacea) in Kambaska, K., Sahoo, S., and Prusti, A. (2008). Effect of plant growth regulator on in-vitro micro propagation of 'bitter yam' (Dioscorea hispida Dennst). International Journal of Integrated Biology, 4(1):50. DOI: http://dx.doi.org/10.1038/1681090a0

Ihekeronye, A. I., and Ngoddy, P.O. (1985). Integrated Food Science and Technology for the tropics. Macmillan Publishers Ltd., London and Basingstoke, Pp. 266-282. DOI: http:// dx.doi.org/10.1017/s0307883300012062

Jayakody, L., Hoover, R., Liu, Q. and Donner, E. (2007). Studies on tuber starches. II. Molecular structure, composition and physicochemical properties of yam (Dioscorea sp.) starches grown in Sri Lanka. Carbohydrate Polymers, 69: 148-163. DOI: http://dx.doi.org/10.1016/j. carbpol.2006.09.024

Kouakou, M.D., Dabonne, S., Guehi, T., and Kuoame, L.P. (2010). Effects of post-harvest storage on some biochemical parameters of different parts of two yams species (Dioscorea spp). African Journal of Food Science and Technology, 1: 1-9. DOI: http://dx.doi.org/10.5251/ abjna.2011.2.4.591.597

Kulkarni, D.K., and Kumbhojkar, M.S. (1993). Kitchen garden plants of Mahadeokali tribe in Maharastra. Ethnobotany, 5:119-127. DOI: http://dx.doi.org/10.2307/1587060

Madziga, H.A., Sanni, S. and Sandabe, U.K. (2010). Phytochemical and Elemental Analysis of Acalypha wilkesiana Leaf. Journal of American Science, 6(11): 510-514. DOI: http://dx.doi. org/10.3923/rjphyto.2008.77.83

O'Hair, S.K. (1990). Tropical root and tuber crops. Timber press, Portland, Pp: 424-428. DOI: http://dx.doi.org/10.1002/9781118060858.ch3

Oladipo, F.Y. and Nwokocha, L.M. (2011). Effect of Sida acuta and Corchorus olitorius mucilages on the physicochemical properties of maize and sorghum starches. Asian Journal of Applied Science, 4: 514-525. DOI: http://dx.doi.org/10.3923/ajaps.2011.514.525

Osagie, A.U. (1992). The yam tuber in storage. Postharvest Research Unit, University of Benin, Benin City, Nigeria. DOI: http://dx.doi.org/10.19070/2167-910x-1500030 
Otoo, E., and Asiedu, R. (2008). GGE biplot analysis of Dioscorearotundata cultivar "Dente" in Ghana. African Journal of Agricultural Resolution, 3:115-125. DOI: http://dx.doi. org/10.1201/9781420040371.sec3

Prohp, T.P. and Onoagbe, I. O. (2012). Determination of phytochemical composition of the stem bark of triplochiton scleroxylon k. schum. (sterculiaceae). International Journal of Applied Biology and Pharmaceutical Technonlogy, 3(2): 68-76. DOI: http://dx.doi.org/10.5455/ jppa.20121221031603

Shanthakumari, S., Mohan, V.R., and de Britto, J. (2008). Nutritional Evaluation and Elimination of Toxic Principles in Wild Yam (Dioscorea specie.), Tropical and Subtropical Agro-systems, 8: 319-325. DOI: http://dx.doi.org/10.1016/s0308-8146(03)00019-0

Sharma, R. (2004). Agro-technique of medicinal plants. Daya Publishing House, New Delhi, 8182. DOI: http://dx.doi.org/10.1002/pad.4230030118

Sofowora, E.A. (1993). Medicinal Plants and Traditional Medicine in Africa. Spectrum Books Ltd, Ibadan, Nigeria. Pp. 289. DOI: http://dx.doi.org/10.2307/4108615

Southgate, D.A.T. (1973). Fibre and other unavailable carbohydrates and their effect on the energy value of diet production. Nutrition Society, 32: 131. DOI: http://dx.doi.org/10.1079/ pns 19730030

Tindall, H.D. (1983). Vegetables in the Tropics. 1st Eds. Macmillan Education Ltd. Hound mills, Hampshire. Pp. 207-221. DOI: http://dx.doi.org/10.1007/978-1-349-17223-8

Trease, G.E and Evans, W.C. (2002). Phytochemicals. In: Pharmacognosy. $15^{\text {th }}$ eds. Saunders Publishers, London. 42-393. DOI: http://dx.doi.org/10.1016/s0367-326x(02)00228-9

Trease, G.E., and Evans, W.C. (1998). Pharmacology. 11 ${ }^{\text {th }}$ Eds, Braillieriere Tindall Ltd., London, 60-75. DOI: http://dx.doi.org/10.1111/j.2042-7158.1949.tb12463.x

Watson, J.D. (1971). Investigation on the nutritive value of some Ghanaian food-stuff. Ghanaian Journal of Agriculture, 4: 95-111. DOI: http://dx.doi.org/10.4141/cjas70-001

Zannou,A. (2006). Socio-economic, agronomic and molecular analysis of yam and cowpea diversity in the Guinea-Sudan transition zone of Benin. Ph.D. Thesis, Wageningen University. DOI: http://dx.doi.org/10.1016/s1573-5214(04)80023-x

Zannou, A., Richards, P., and Struik, P.C. (2006). Knowledge on yam variety development: Insights from farmers' and researchers' practices. Knowledge, Management and Developmental Journal, 2 (3): 30-39. DOI: http://dx.doi.org/10.1016/s1573-5214(04)80023-x 